\title{
Intestinal Absorption of Hemoglobin Iron-Heme Cleavage by Mucosal Heme Oxygenase
}

\author{
Steven B. Raffin, Choong H. Woo, Kenneth T. Roost, \\ Davm C. Price, and Rudi Schmm \\ From the Gastrointestinal Unit, Department of Medicine, and Nuclear Medicine \\ Section, Department of Radiology, University of California School of Medicine, \\ San Francisco, California 94143
}

A B S T R A C T Hemoglobin and myoglobin are a major source of dietary iron in man. Heme, separated from these hemoproteins by intraluminal proteolysis, is absorbed intact by the intestinal mucosa. The absorbed heme is cleaved in the mucosal cell releasing inorganic iron. Although this mucosal heme-splitting activity initially was ascribed to xanthine oxidase, we investigated the possibility that it is catalyzed by microsomal heme oxygenase, an enzyme which converts heme to bilirubin, $\mathrm{CO}$, and inorganic iron.

Microsomes prepared from rat intestinal mucosa contain enzymatic activity similar to that of heme oxygenase in liver and spleen. The intestinal enzyme requires NADPH; is completely inhibited by $50 \% \mathrm{CO}$; and produces bilirubin IX- $\alpha$, identified spectrophotometrically and chromatographically. Moreover, duodenal heme oxygenase was shown to release inorganic ${ }^{55} \mathrm{Fe}$ from ${ }^{55} \mathrm{Fe}$-heme. Along the intestinal tract, enzyme activity was found to be highest in the duodenum where hemoglobin iron absorption is reported to be most active. Furthermore, when rats were made iron deficient, duodenal heme oxygenase activity and hemoglobin-iron absorption rose to a comparable extent. Upon iron repletion of iron-deficient animals, duodenal enzyme activity returned towards control values. In contrast to heme oxygenase, duodenal xanthine oxidase activity fell sharply in iron deficiency and rose towards base line upon iron repletion.

Our findings suggest that mucosal heme oxygenase catalyzes the cleavage of heme absorbed in the intestinal mucosa and thus plays an important role in the absorption of hemoglobin iron. The mechanisms controlling this intestinal enzyme activity and the en-

This work was presented in part at the Annual Meeting of the American Society for Clinical Investigation in Atlantic City, N. J., 5 May 1974.

Received for publication 12 June 1974 and in revised form 9 August 1974. zyme's role in the overall regulation of hemoglobin-iron absorption remain to be defined.

\section{INTRODUCTION}

Inorganic iron salts and the heme ${ }^{1}$ iron of hemoglobin, myoglobin, and other hemoproteins represent the major dietary sources of iron in carnivorous mammals (1-4). Intestinal absorption of these inorganic and organic iron compounds is most active in the duodenum and is adaptively increased in iron deficiency (5-9). Studies with tracer techniques indicated that in man a major portion of the absorbed food iron is derived from ingested heme compounds $(3,4)$. Thus, it has been shown in normal individuals that the fractional absorption of radioactive iron from food containing comparable amounts of either inorganic ${ }^{50} \mathrm{Fe}$-salts or ${ }^{60} \mathrm{Fe}$ hemoglobin was 0.9 and $15.8 \%$ of the administered dose, respectively (3). In the omnivorous rat, on the other hand, the importance of hemoglobin iron as a source of food iron is a matter of controversy. Weanling rats, raised on a diet in which hemoglobin was the only source of iron, were shown to develop iron deficiency, reflected by hypochromic microcytic anemia (10). Furthermore, despite this iron deficiency, fractional absorption of hemoglobin iron did not rise, which suggested that hemoglobin iron is poorly absorbed in rats $(8,10)$. By contrast, Bannerman (11) and Wheby, Suttle, and Ford (9) found that rats are able to absorb hemoglobin iron, although at a smaller rate than ferrous salts, and that the absorption of heme iron is adaptive in that it increases in iron deficiency. Moreover, Thomas, McCullough, and Greenberger (12) reported that in rats, intraperitoneal administration of

\footnotetext{
'In this paper, the term "heme" is used to indicate ironprotoporphyrin IX without regard to the oxidation state of the iron.
} 
phenobarbital enhances intestinal absorption of hemoglobin iron.

In contrast to iron salts, intestinal absorption of hemoglobin iron is neither reduced by simultaneous administration of food or chelators, nor is it enhanced by ascorbic acid $(2,3,13,14)$. These observations suggest that hemoglobin iron is absorbed in a manner different from that of inorganic iron salts. It is presumed that native or partly denatured hemoglobin or myoglobin that has reached the gastrointestinal tract is split by proteolytic enzymes into polypeptides and heme $(9,15)$. The heme, containing the chelated iron in the core of the protoporphyrin ring, then is believed to be transferred intact into the intestinal mucosa, wherein the ferroprotoporphyrin is cleaved and the iron set free $(9,14)$. This latter conclusion is based on the observation that after intestinal administration of labeled hemoglobin to dogs, most of the isotopic iron appeared in the portal circulation in the form of transferrin-bound iron rather than as intact heme (14, 16).

Weintraub, Weinstein, Huser, and Rafal (14) provided evidence that intramucosal disruption of the absorbed heme is an enzymatic process, and subsequent studies appeared to suggest that the enzyme involved may be xanthine oxidase (17). This enzyme, which catalyzes the conversion of hypoxanthine and xanthine to uric acid, generates hydrogen peroxide which, according to one school of thought (18), may be involved in the fissure of methene carbon bridges of ferroprotoporphyrin. The major objection to this proposed mechanism is that it would be expected to result in formation of a mixture of bilirubin isomers which is at variance with the findings in vivo $(19,20)$. As an alternate possibility, we have proposed that mucosal heme-splitting enzyme activity may reflect microsomal heme oxygenase (21), which in many other tissues catalyzes the conversion of heme to bilirubin IX- $\alpha, \mathrm{CO}$, and inorganic iron (21-23). However, initial attempts to identify heme oxygenase activity in the intestinal mucosal of rats, rabbits, and dogs were unsuccessful. The fortuitous observation that intestinal and possibly pancreatic proteases rapidly inactivate the mucosal heme-splitting enzyme activity permitted reassessment of this problem.

In the present study, we demonstrate that rat intestinal mucosa contains a microsomal enzyme with properties and activity similar to microsomal heme oxygenase in liver (22). Intestinal heme oxygenase activity is highest in the mucosa of the duodenum, where hemoglobin iron is absorbed most efficiently $(8,9)$. Moreover, when body iron stores are experimentally altered, resulting in adaptive changes in the rate of hemoglobin iron absorption, heme oxygenase activity in duodenal mucosa changes in a parallel manner. These observations suggest that microsomal heme oxygenase may play a role in the intestinal absorption of hemoglobin iron.

\section{METHODS}

Analytical techniques. All experiments were conducted in male Sprague-Dawley rats $(130-300 \mathrm{~g})$ purchased from Charles River Breeding Laboratories, Inc., Wilmington, Mass., and certified to be "specific pathogen" (Bartonella)free. The animals were housed two to a cage in an isolated room of the vivarium equipped with automatically controlled temperature and $12 \mathrm{~h}$-diurnal photoperiods. Cages had wire mesh floors, precluding the possibility of coprophagia.

Intestinal mucosa for enzyme assay was prepared as follows: under light ether anesthesia, the rats were exsanguinated by aortic puncture and three $10-\mathrm{cm}$ segments of small intestine were excised and perfused with $30 \mathrm{ml}$ of isotonic $\mathrm{NaCl}$ at $4^{\circ} \mathrm{C}$ to wash out intestinal contents. For convenience, we chose the first $10-\mathrm{cm}$ segment distal to the pylorus (duodenum), the fourth $10-\mathrm{cm}$ segment (jejunum), and the terminal $10-\mathrm{cm}$ segment (ileum). The mucosa was extruded on a chilled glass plate by stroking the serosa with a glass slide, producing clumps of epithelial cells easily identified by microscopic examination. The mucosal cells were suspended in $5 \mathrm{ml}$ of ice-cold $0.1 \mathrm{M} \mathrm{K}$ phosphate buffer, $\mathrm{pH} 7.4$, containing $5 \%$ (vol/vol) fetal calf serum (Grand Island Biological Co., Grand Island, N. Y.). Addition of fetal calf serum appeared essential, as in its absence enzyme activity was rapidly lost; fetal calf serum neither possesses intrinsic heme oxygenase activity nor does it affect enzyme activity when added to splenic microsomes. The cell suspension was weighed and sonicated for $25 \mathrm{~s}$ at $35 \mathrm{~W}$ (Sonifier cell disruptor, Heat Systems-Ultrasonics, Inc., Plainview, N. Y., model W185D), which virtually disrupted all cells as shown by phase microscopy. A Sorvall superspeed automatic refrigerated centrifuge (model RC 2-B, Ivan Sorvall, Inc., Norwalk, Conn.) and a Beckman model L-2 ultracentrifuge (Beckman Instruments, Inc., Fullerton, Calif.) were used to prepare $20,000-g$ supernate and microsomal fractions using a minor modification of the method of Schneider (24). In most instances, assay of heme oxygenase was performed in the $20,000-g$ supernatant fraction (22). A typical incubation mixture $(0.5 \mathrm{ml})$ contained $0.1 \mathrm{ml}$ of the $20,000-\mathrm{g}$ supernatant fraction (protein concentration approximately $8 \mathrm{mg} / \mathrm{ml}$ ); $80 \mathrm{mM} \mathrm{K}$ phosphate buffer, $\mathrm{pH} 7.4 ; 180 \mu \mathrm{M}$ NADPH, and $45 \mu \mathrm{M}$ hemin as methemalbumin (MHA) ${ }^{2}$ containing $22 \mu \mathrm{mol} \mathrm{hemin} / \mu \mathrm{mol}$ albumin. Enzyme activity was expressed as nmol bilirubin formed $/ \mathrm{min} / 10 \mathrm{mg}$ protein, using 60,000 as the molar extinction coefficient of bilirubin as determined in our assay mixture. The techniques of McDonagh and Assisi (25) were used to extract, purify, and identify the isomer form of the enzymatically produced bilirubin. Absorption spectra were determined in an Aminco DW-2 spectrophotometer (American Instrument Co., Inc., Silver Spring, Md.).

In addition to the conventional assay method for microsomal heme oxygenase, a new procedure was developed which demonstrates directly the release of radioactive iron

-Abbreviations used in this paper: $\mathrm{MCHC}$, mean corpuscular hemoglobin concentration; $\mathrm{MCV}$, mean corpuscular erythrocyte volume; MHA, methemalbumin; NBLI diet, Nutritional Biochemicals low iron diet. 


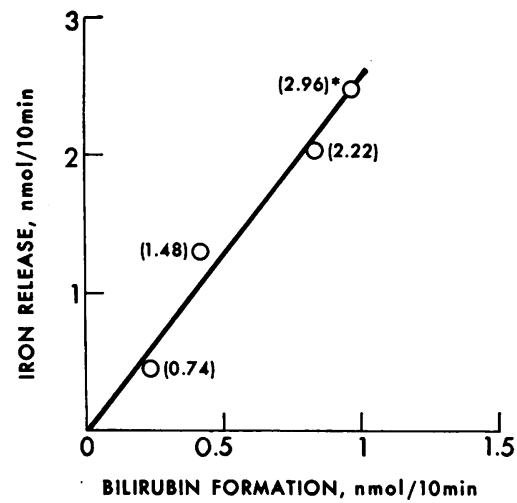

Figure 1 Comparison between bilirubin formation and iron release by microsomal heme oxygenase in the same $20,000-g$ supernatant fraction prepared from rat spleen. Each point represents the mean of four individual determinations at the indicated protein concentrations. (*) Protein concentration, milligrams per milliliter.

from ${ }^{55} \mathrm{Fe}-\mathrm{MHA}$. A typical assay mixture $(1.0 \mathrm{ml})$ contained $0.2 \mathrm{ml}$ of the $20,000-g$ supernatant fraction (protein concentration approximately $8 \mathrm{mg} / \mathrm{ml}$ ) ; $80 \mathrm{mM} \mathrm{K}$ phosphate buffer, $\mathrm{pH} \quad 7.4 ; 45 \mu \mathrm{M}{ }^{55} \mathrm{Fe}-\mathrm{MHA}$ containing 0.023 $\mu \mathrm{Ci}{ }^{50} \mathrm{Fe}(26)$; and $180 \mu \mathrm{M}$ NADPH. The mixture was incubated with gentle agitation at $37^{\circ} \mathrm{C}$ for $12 \mathrm{~min}$ in a Metabolyte water bath shaker (New Brunswick Scientific Co. Inc., New Brunswick, N. J.). The inorganic ${ }^{55} \mathrm{Fe}$ released enzymatically was precipitated from the reaction mixture, solubilized, and quantitated in the following manner. $2 \mathrm{ml}$ of 5 $\mathrm{N} \mathrm{NaOH}$ were added to each $1 \mathrm{ml}$ of the incubation mixture together with $5 \mathrm{mg}$ of ferric ammonium citrate $(0.75$ $\mathrm{mg}$ iron) and $1 \mathrm{mg}$ crystalline hemin (Sigma Chemical Co., St. Louis, Mo.). The ferric ammonium citrate was required for coprecipitation of free ${ }^{55} \mathrm{Fe}$ as ferric hydroxide, while the added hemin served to dilute the remaining unreacted ${ }^{55} \mathrm{Fe}$-hemin that tended to get trapped in the bulky ferric hydroxide precipitate. The whole mixture was then placed in a boiling water bath for $15 \mathrm{~min}$, centrifuged for $10 \mathrm{~min}$ at $2,000 \mathrm{rpm}$, and the supernate, containing more than $97 \%$ of the unreacted ${ }^{55} \mathrm{Fe}$-hemin, was discarded. The ferric hydroxide pellet containing the enzymatically released ${ }^{50} \mathrm{Fe}$ was further cleansed of trapped ${ }^{55} \mathrm{Fe}$-hemin by dissolving it three times in $1 \mathrm{~N} \mathrm{HCl}$, followed by precipitation with $1 \mathrm{~N} \mathrm{NaOH}$. By this means, contamination of the $\mathrm{Fe}(\mathrm{OH})_{3}$ pellet with unreacted ${ }^{5} \mathrm{Fe}$-hemin eventually was reduced to $2-3 \%(500-600 \mathrm{cpm})$ of the initial $45 \mathrm{nmol}$ of substrate added $(20,000 \mathrm{cpm})$. Finally, the pellet containing the ${ }^{85} \mathrm{Fe}$ was dissolved and decolorized by the addition of $0.3 \mathrm{ml} 1 \mathrm{~N} \mathrm{HCl}$ and $0.4 \mathrm{ml} 5 \%$ (wt/vol) aqueous ascorbate. The clear and colorless solution was added to $15 \mathrm{ml}$ of scintillation fluid, consisting of $10 \%$ (vol/vol) BBS-3 and $32 \mathrm{~g}$ of dry mix formula TLA fluor (Beckman Instruments, Inc.) in 1 gallon of toluene. The radioactive iron was counted in a Beckman liquid scintillation spectrometer (model LS-250, Beckman Instruments, Inc.), utilizing the wide ${ }^{8} \mathrm{H}$ isoset module (27). When traces of ${ }^{50} \mathrm{FeCl}_{3}$ were added to the initial assay mixture, recovery of the isotope ranged from 84 to $85 \%$. Quenching of individual samples was monitored by external standardization and was found to vary by less than $1 \%$. Results were expressed as nmol inorganic iron released $/ \mathrm{min} / 10 \mathrm{mg}$ protein of the incubation mixture. Using variable amounts of a $20,000-g$ super- natant fraction of spleen as the enzyme source, enzyme activity determined with this modified assay procedure was proportional to the values obtained with the conventional microsomal heme oxygenase assay (Fig. 1).

Intestinal xanthine oxidase was assayed by a modification of the method of Dawson, Rafal, and Weintraub (17) using a 20,000-g supernatant fraction of sonicated mucosal cells. The incubation mixture contained $0.2 \mathrm{ml}$ of the supernatant fraction (protein concentration, $8 \mathrm{mg} / \mathrm{ml}$ ), and 4.8 $\mathrm{ml}$ of an ice-cold solution containing $5 \times 10^{-6} \mathrm{M}$ xanthine in $0.1 \mathrm{M}$ tris- $\mathrm{HCl}$ buffer, $\mathrm{pH}$ 8.3. A portion of this mixture was transferred to a $3.0-\mathrm{ml}$ cuvette, placed in a Gilford recording spectrophotometer (Gilford Instrument Laboratories, Inc., Oberlin, Ohio) prewarmed to $37^{\circ} \mathrm{C}$, and the reaction allowed to proceed to completion. Formation of uric acid was continuously monitored by the change in optical density (OD) at $292 \mathrm{~nm}$. Results were expressed as $\Delta \mathrm{OD} / \mathrm{min} / 10 \mathrm{mg}$ protein. Allopurinol added to the incubation mixture (final concentration $2 \times 10^{-4} \mathrm{M}$ ) completely inhibited the reaction. Moreover, $10 \mu 1$ of porcine uricase (2 $\mathrm{U} / \mathrm{ml}$, Sigma Chemical Co.) added to the reaction mixture after the initial $15 \mathrm{~min}$ of incubation caused the disappearance of the OD at $292 \mathrm{~nm}$ that had been generated during the initial phase of incubation.

Intestinal absorption of hemoglobin iron in the intact rat was quantitated in the following manner. $30 \mathrm{mg}$ rat ${ }^{50} \mathrm{Fe}-$ hemoglobin $\left(0.75 \mu \mathrm{Ci}{ }^{50} \mathrm{Fe}\right)$ prepared by the method of Thomas et al. (12) and dissolved in $2 \mathrm{ml}$ of dilute tris$\mathrm{HCl}$ buffer, $\mathrm{pH} 8.6$, was instilled intragastrically in rats that had been fasted for the preceding $24 \mathrm{~h}$. Whole body radioactivity of the animals was determined using a dualdetector large sample gamma counting system (Tobor, Nuclear-Chicago Corp., Des Plaines, III.). 10-min counts were performed $3 \mathrm{~h}$ after the ${ }^{50} \mathrm{Fe}$-hemoglobin instillation and again 7 days later (28). Absorption of ${ }^{50} \mathrm{Fe}$-hemoglobin was expressed as the percentage of administered isotope retained 7 days after intragastric infusion.

Serum iron was measured by the method of Stookey (29) and protein concentration was determined by the method of Lowry, Rosebrough, Farr, and Randall (30). In some instances iron-deficient rats were repleted with $50 \mathrm{mg}$ iron by intramuscular injection of iron dextran (Imferon, Lakeside Laboratories, Milwaukee, Wisc.) 7 days before study.

Experimental iron deficiency in rats. In young, rapidly growing male Sprague-Dawley rats weighing 130-200 g, iron deficiency was produced by feeding a low iron diet (Nutritional Biochemicals Corp., Cleveland, Ohio [NBLI diet]), consisting of vitamin test casein, $27 \%$; corn starch, $55 \%$; hydrogenated vegetable oil, $14 \%$; salt mixture without ferric phosphate, $3 \%$; and vitamin mixture, $1 \%$. The iron content of this NBLI diet was less than $0.1 \mathrm{mg} / 100 \mathrm{~g}$ diet (The Hine Labs, San Francisco, Calif.). Control animals were fed either standard rat chow containing $20 \mathrm{mg}$ iron $/ 100 \mathrm{~g}$ diet (Berkeley Diet, Seed Stuff Processing Co., San Francisco, Calif.) or the NBLI diet supplemented with ferrous sulfate ( $40 \mathrm{mg}$ iron/100 g diet). No difference in hematocrit, serum iron concentration, or intestinal microsomal heme oxygenase activity was detected between groups of rats maintained on these two control diets. The growth rate of animals fed the iron-deficient NBLI diet was comparable with that of littermates maintained on either of the control diets. In rats on the NBLI diet, serum iron concentration and hematocrit fell within the 1st wk (Fig. 2), confirming earlier findings by McCall, Newman, O'Brien, Valberg, and Witts (31) in weanling rats on a similar low iron diet. After 20 days on the NBLI diet, hemoglobin concentration and mean corpuscular erythrocyte volume 


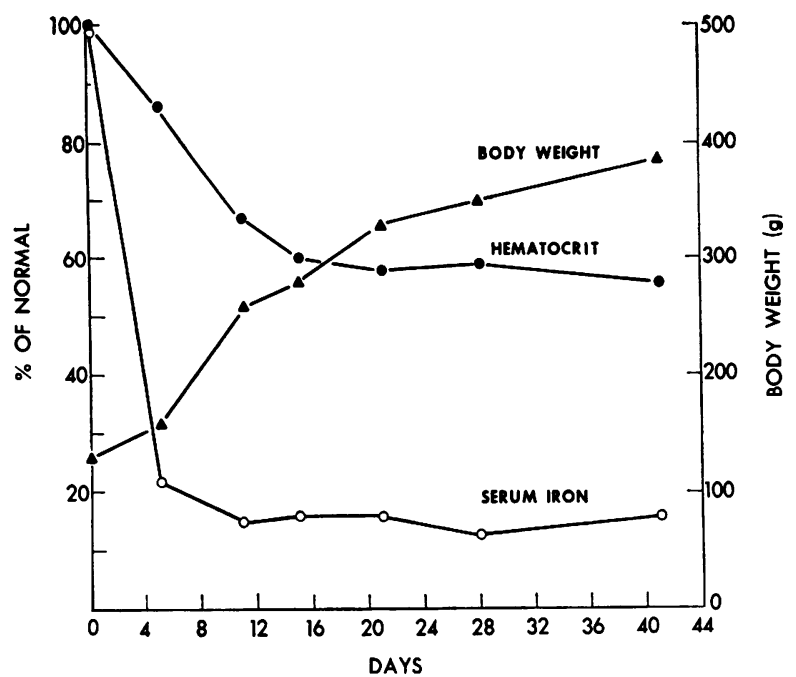

FIgURE 2 Serum iron, hematocrit, and growth rate of rats fed a low iron diet. 14 rats fed NBLI diet were killed at the times indicated. Each point represents the average value of two animals. Normal serum iron concentration and hematocrit were $252 \mu \mathrm{g} / 100 \mathrm{ml}$ and $45 \%$, respectively; mean values after 2 wk on NBLI diet were $39 \mu \mathrm{g} / 100 \mathrm{ml}$ and $30 \%$, respectively.

(MCV) were substantially reduced and after 34 days, the red cells were distinctly hypochromic as judged by mean corpuscular hemoglobin concentration (MCHC) (Table I). In rats which had been fed the NBLI diet for 20 days, substitution of drinking water by $1 \%$ aqueous ferrous sulfate solution for 7 days corrected the iron deficiency.

\section{RESULTS}

Intestinal absorption of hemoglobin iron in rats. Because of the existing controversy regarding the extent of hemoglobin iron absorption in rats, we estimated the fractional isotope absorption of intragastrically administered, ${ }^{50} \mathrm{Fe}$-labeled hemoglobin in four control and four iron-deficient rats. The iron-deficient animals were maintained on the NBLI diet for 3 wk before the study and had a mean serum iron concentration of $39 \mu \mathrm{g} / 100 \mathrm{ml}$. In the control rats, hemoglobin iron absorption was $2.5 \pm 0.4 \%$ (SEM) of the administered dose whereas in the iron-deficient animals, the respective value rose to $5.8 \pm 0.6 \%$. Our results in normal rats are identical to those of Thomas et al. (12) who, under comparable experimental conditions, reported a fractional isotope absorption of $2.5 \pm 0.4 \%$ (SD). Moreover, the data in iron-deficient rats are in agreement with the earlier reports of Bannerman (11) and Wheby et al. (9) who demonstrated an increase in hemoglobin iron absorption in rats with depleted iron stores.

Characterization of the intestinal heme-splitting enzyme. Rat intestinal mucosa was shown to contain an enzyme system exhibiting many of the characteristics
TABLE I

Hematological Values in Normal and Iron-Deficient Rats

\begin{tabular}{|c|c|c|c|c|c|c|}
\hline & \multicolumn{2}{|c|}{ Normal diet $(n=5)$} & \multicolumn{4}{|c|}{ NBLI* $\operatorname{diet}(n=6)$} \\
\hline & & & \multicolumn{2}{|r|}{20 days } & \multicolumn{2}{|r|}{34 days } \\
\hline $\mathrm{Hb}, \mathrm{g} / 100 \mathrm{ml}$ & 15.6 & $(14.7-16.1) \ddagger$ & 10.8 & $(10.1-11.3)$ & 7. & $(6.7-9.2)$ \\
\hline Hct, \% & 45 & $(41-48)$ & 30 & $(26-32)$ & 27 & $(24-30)$ \\
\hline $\mathrm{MCV}, \mu m^{2}$ & 55 & $(52-57)$ & 51 & $(50-52)$ & 45 & $(44-45)$ \\
\hline MCHC, \% & 34 & $(33-36)$ & 35 & $(33-37)$ & 29 & $(28-31)$ \\
\hline $\begin{array}{l}\text { Serum iron, } \\
\mu g / 100 \mathrm{ml}\end{array}$ & 252 & $(223-271)$ & 39 & $(35-41)$ & 37 & $(33-42)$ \\
\hline
\end{tabular}

* See Methods, footnote 2, for abbreviations.

$\ddagger$ Results are given as mean and range.

of microsomal heme oxygenase which in other tissues catalyzes the conversion of heme to bilirubin (21-23). Intestinal enzyme activity was present in microsomes prepared from the mucosa but was absent from the 100 ,$000-g$ supernatant fraction. MHA served as substrate and its conversion to bilirubin was linear during the first $12 \mathrm{~min}$ of incubation. In the $20,000-\mathrm{g}$ supernatant fraction of duodenal mucosa, formation of bilirubin was proportional to protein concentration up to $3 \mathrm{mg} /$ $\mathrm{ml}$ (Fig. 3). The reaction required NADPH and aerobic conditions, was inactive at $4^{\circ} \mathrm{C}$, and was completely inhibited by $50 \% \mathrm{CO}$. When the bilirubin (formed on incubation of the complete system) was extracted with chloroform, its $R_{f}$ in two different thin-layer chromatography (TLC) systems (silica gel, chloroform with $1 \%$ [vol/vol] acetic acid; and polyamide, methyl alcohol with $1 \%$ [vol/vol] ammonium hydroxide) was identical with that of authentic bilirubin IX- $\alpha$ prepared from a mixture of isomers contained in commercial

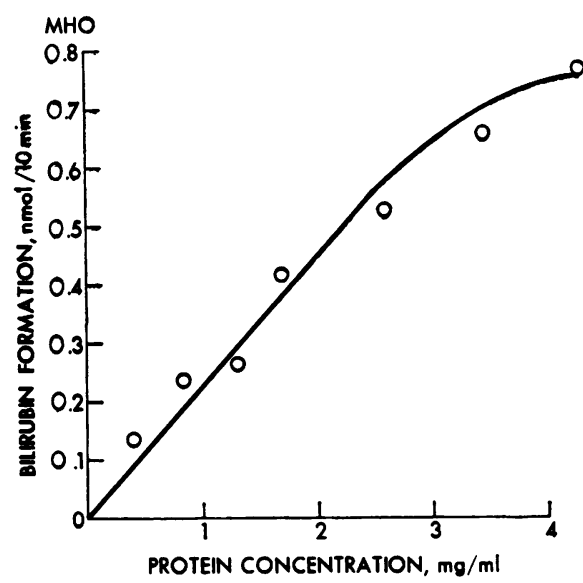

Figure 3 Reaction rate as a function of enzyme concentration. Heme oxygenase activity, expressed as nanomole bilirubin formed in $10 \mathrm{~min}$, was measured in the $20,000-g$ supernatant fraction of duodenal mucosa obtained from two iron-deficient rats. Each point represents the average value of two separate determinations at the protein concentrations indicated on the abscissa. 


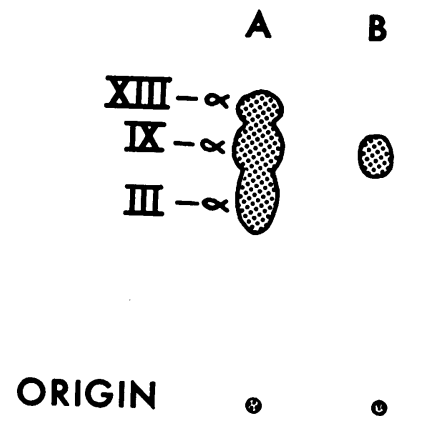

Frgure 4 Facsimile of thin-layer chromatogram of bilirubin formed by duodenal microsomal heme oxygenase The $R_{f}$ of bilirubin formed by duodenal heme oxygenase (B) is identical with that of authentic bilirubin IX- $\alpha$ (A) but differs from the $R_{f}$ of the bilirubin isomers III- $\alpha$ and XIII- $\alpha$ contained in commercial bilirubin (Pfanstiehl Laboratories Inc., Waukegan, Ill.).

bilirubin (25); it clearly differed from the $R_{f}$ of bilirubin III- $\alpha$ and XIII- $\alpha$ (Fig. 4). In addition, when mixtures containing the enzymatically formed bilirubin and authentic bilirubin IX- $\alpha$ were applied to either TLC system, they migrated as a single spot suggesting identity of these two pigments. Finally, the absorption spectrum of the enzymatically formed bilirubin eluted from the silica gel TLC was virtually identical with that of authentic bilirubin IX- $\alpha$.
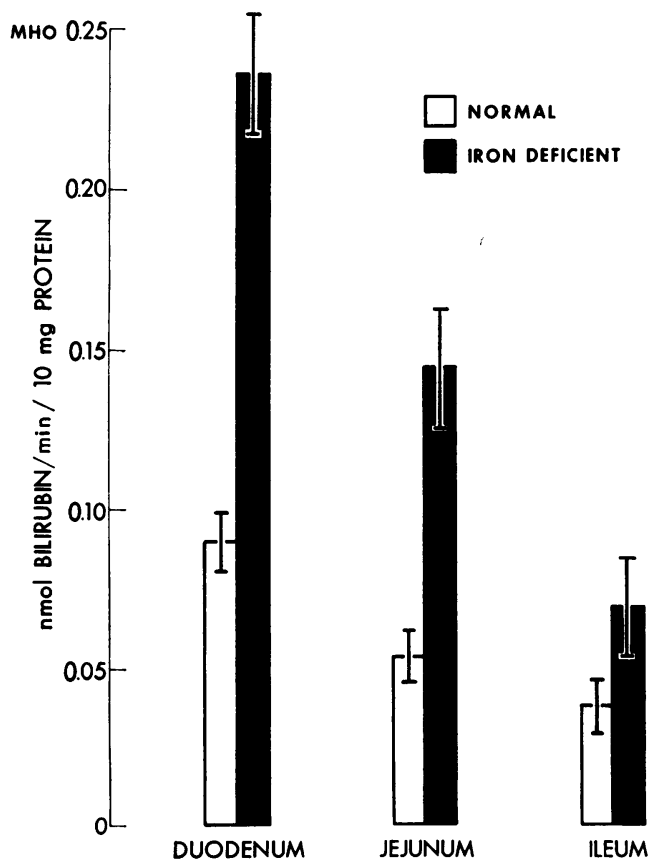

FIgURe 5 Microsomal heme oxygenase activity in the intestinal mucosa of normal and iron-deficient rats. Enzyme assays were carried out in the $20,000-g$ supernatant fraction of mucosa of intestinal segments obtained from four normal and eight iron-deficient rats. Results are expressed as mean \pm SEM.

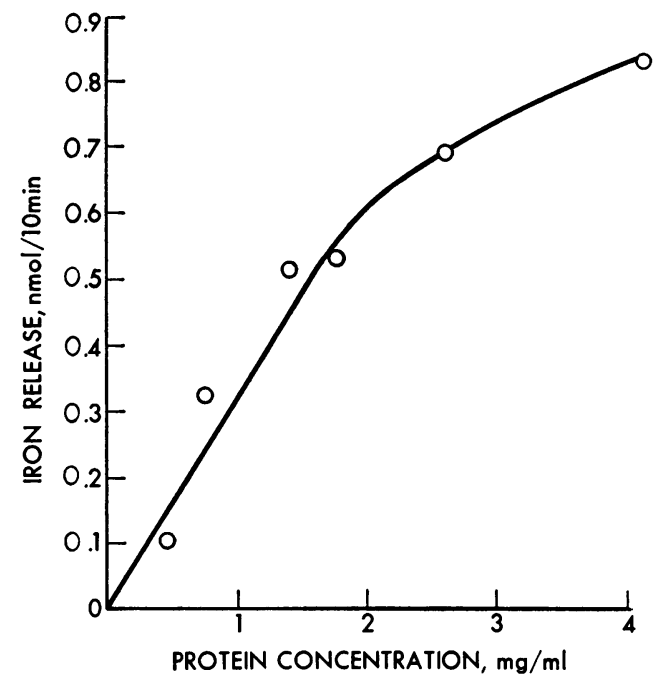

FIgURE 6 Reaction rate as a function of enzyme concentration. Heme oxygenase activity, expressed as nanomole iron released in $10 \mathrm{~min}$, was measured in the 20,000-g supernatant fraction of duodenal mucosa obtained from two normal rats. Each point represents the average value of two separate determinations at the protein concentrations indicated on the abscissa.

Microsomal heme oxygenase activity was highest in duodenal mucosa where absorption of hemoglobin iron is reported to be most effective $(8,9)$ and progressively fell in more caudal intestinal segments (Fig. 5). This quantitative relationship existed whether enzyme activity was expressed as specific activity per milligram

TABLE II

Duodenal Heme Oxygenase Activity in Normal, Iron-Deficient, and Iron-Repleted Rats

\begin{tabular}{|c|c|c|c|c|}
\hline & Hematocrit & $\begin{array}{c}\text { Serum } \\
\text { iron }\end{array}$ & $\begin{array}{l}\text { Bilirubin } \\
\text { formed }\end{array}$ & $\begin{array}{l}\text { Heme iron } \\
\text { released }\end{array}$ \\
\hline & $\%$ & $\mu \mathrm{g} / 100 \mathrm{ml}$ & $\begin{array}{c}\text { nmol/min/ } \\
10 \mathrm{mg} \\
\text { protein }\end{array}$ & $\begin{array}{c}\text { nmol/min/ } \\
10 \mathrm{mg} \\
\text { protein }\end{array}$ \\
\hline $\begin{array}{l}\text { Normal rats } \\
\quad(n=4)\end{array}$ & $43 \pm 2.0$ & $250 \pm 5.0$ & $0.14 \pm 0.01$ & $0.27 \pm 0.02$ \\
\hline $\begin{array}{l}\text { Iron-deficient } \\
\quad \text { rats } \\
\quad(n=4)\end{array}$ & $27 \pm 0.5$ & $41 \pm 1.0$ & $0.38 \pm 0.01$ & $0.45 \pm 0.04$ \\
\hline $\begin{array}{l}\text { Iron-repleted* } \\
\quad \text { rats } \\
\quad(n=4)\end{array}$ & $42 \pm 0.5$ & $167 \pm 15.0$ & $0.16 \pm 0.01$ & $0.29 \pm 0.05$ \\
\hline
\end{tabular}

In each rat, both bilirubin formation and heme iron release were measured in the same $20,000-g$ supernatant fraction. Values are expressed as mean $\pm \mathrm{SEM}$.

* Iron-deficient rats $i$ wk after an intramuscular injection of $50 \mathrm{mg}$ iron as iron-dextran (Imferon). 
of the assayed protein or as total activity of the $10-\mathrm{cm}$ intestinal segment.

When intestinal heme oxygenase was assayed by the modified procedure which permits direct quantitation of the inorganic ${ }^{56} \mathrm{Fe}$ released from ${ }^{55} \mathrm{Fe}$-heme, the results were similar to those obtained with the conventional enzyme assay. Iron-releasing activity was present in the microsomal fraction of intestinal mucosa, but not in the $100,000-g$ supernatant fraction. NADPH and aerobic conditions were essential for activity, whereas incubation at $4^{\circ} \mathrm{C}$ or in the presence of $50 \%$ $\mathrm{CO}$ completely inhibited enzyme activity. The reaction rate was linear for the first $15 \mathrm{~min}$ of incubation and was proportional to protein concentration up to 2.0 $\mathrm{mg} / \mathrm{ml}$ (Fig. 6).

Relationship of duodenal heme oxygenase activity to hemoglobin iron absorption. Since fractional hemoglobin iron absorption was found to be increased in iron deficiency, intestinal heme oxygenase was assayed in rats whose iron stores had been depleted. In this group of anemic animals, mean serum iron concentration and hematocrit were $39 \mu \mathrm{g} / 100 \mathrm{ml}$ serum and $30 \%$, respectively, compared to normal values of $252 \mu \mathrm{g} / 100$ $\mathrm{ml}$ serum and 45\% (Table I). All three intestinal segments exhibited an increase of mucosal heme oxygenase activity in iron deficiency (Fig. 5); duodenal and jejunal enzyme activity was raised approximately $2 \frac{1}{2}$-fold over control values $(P<0.001)$. Moreover,

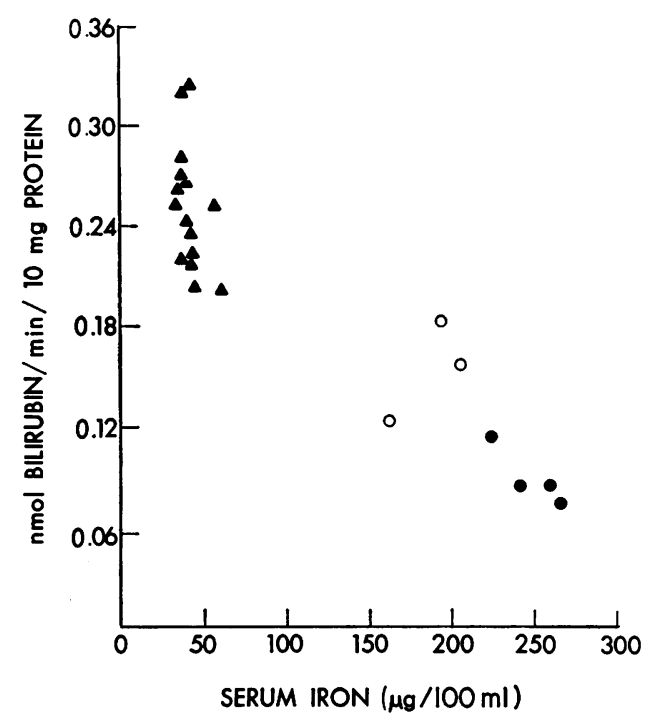

FIGURE 7 Relationship of duodenal heme oxygenase activity to serum iron concentration. The symbols indicate values in individual rats in one of the following treatment groups: ( $\Delta)$, iron-deficient rats maintained for at least 2 wk on NBLI diet; $(O)$, iron-deficient rats injected intramuscularly with $50 \mathrm{mg}$ iron as iron-dextran (Imferon) 1 wk before the enzyme assay; (๑), control rats on a regular diet.

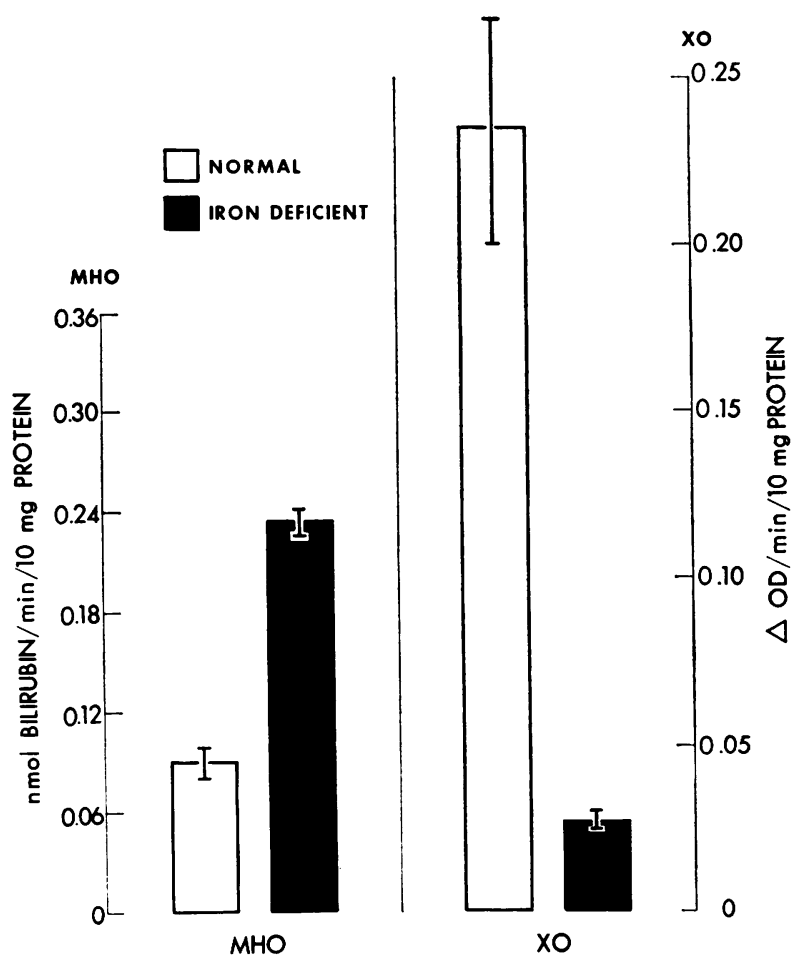

FigURE 8 Microsomal heme oxygenase (MHO) and xanthine oxidase (XO) activity in duodenal mucosa of normal and iron-deficient rats. Enzyme assays were carried out in the 20,000-g supernatant fraction of four normal and eight iron-deficient rats. Results are expressed as mean $\pm \mathrm{SEM}$.

after parenteral iron repletion of iron-deficient rats, duodenal heme oxygenase activity returned towards normal (Table II). This relationship between normal, iron-deficient, and iron-repleted animals held true whether duodenal enzyme activity was expressed in terms of bilirubin formation or of release of heme iron (Table II); in all but one instance $(P<0.05)$, the differences between iron-deficient rats and either normal or iron-repleted animals was statistically significant at the $P<0.01$ level. In addition, in these three groups of rats, a direct proportionality existed between duodenal enzyme activity and serum iron concentration (Fig. 7). In contrast, xanthine oxidase activity, which is relatively high in the duodenal mucosa of normal rats, fell sharply when the animals were rendered iron deficient (Fig. 8), confirming an earlier report by Awai and Brown (32).

\section{DISCUSSION}

The present findings demonstrate that the microsomal fraction of rat intestinal mucosa contains an enzyme system with the characteristics of heme oxygenase (2123). This intestinal enzyme converts protoheme to bilirubin IX- $\alpha$, which is the bilirubin isomer excreted in mammalian bile $(19,20)$. Although isomer identifica- 
tion was carried out with the most sensitive and discriminating techniques published (25), the unavailability of authentic bilirubin IX- $\beta, \gamma$, or $\delta$ for use as standards prevented us from ruling out the possibility that, in addition to bilirubin IX- $\alpha$, small amounts of these "nonphysiological" bilirubin isomers also may have been formed in the enzymatic degradation of heme in vitro.

In the conventional heme oxygenase assay, enzyme activity is measured by the rate of bilirubin formation (22). Since the present study was designed to explore the possible role of intestinal heme oxygenase in the absorption of hemoglobin iron, an attempt was made to modify the enzyme assay in such a way that mucosal release of heme iron could be measured directly. The anticipated technical difficulty of separating the released inorganic ${ }^{55} \mathrm{Fe}$ from the unreacted iron-labeled heme (33) was overcome by a series of precipitation and dissolution steps. With ${ }^{55} \mathrm{Fe}$-protoheme as substrate, the release of inorganic ${ }^{55} \mathrm{Fe}$ was linear and proportional to bilirubin formation over a wide range of enzyme concentrations (Figs. 1 and 6). As expected, however, on a molar basis heme oxygenase-mediated iron release significantly exceeded bilirubin formation. It previously had been noted that with microsomal heme oxygenase prepared from other tissues, heme disappearance from the incubation mixture regularly was greater than the amount of bilirubin formed $(23,34)$. The most likely explanations for this discrepancy are that in the enzymatic cleavage of the ferroprotoporphyrin ring, part of the tetrapyrrol is converted to catabolites different from bilirubin, or that because of the inherent instability of the pigment, part of the bilirubin formed is destroyed during the assay procedure (23).

Since earlier studies had demonstrated that heme absorbed from the intestinal lumen is cleaved within the mucosa $(9,14)$, we postulated that this step may be catalyzed by microsomal heme oxygenase as it is in a variety of other tissues, including spleen and liver (22), kidney (21), and macrophages (23). Our present observations in rats support this concept; thus, in the small intestine, microsomal heme oxygenase activity was highest in the mucosa of the duodenum where hemoglobin iron absorption has been shown to be most efficient $(8,9)$ (Fig. 5). Moreover, in rats made iron deficient, hemoglobin iron absorption and duodenal heme oxygenase activity rose to a comparable extent. Finally, on iron repletion, which would be expected to result in normalization of hemoglobin iron absorption, duodenal heme oxygenase activity returned towards base-line value (Fig. 7, Table II). By contrast, the activity of mucosal xanthine oxidase, which tentatively had been assigned a role in the degradation of absorbed heme (17), greatly declined in iron de- ficiency (Fig. 8), making it unlikely that this soluble enzyme is involved in the absorption and release of heme iron.

If microsomal heme oxygenase catalyzes the degradation of absorbed heme in the intestinal mucosa, it was to be expected that enzyme activity would be increased when heme iron absorption is enhanced in iron deficiency. Although this was the case, it is not clear whether the rise in enzyme activity is a primary event, exerting a regulatory effect on the overall process of heme iron absorption, or whether the enzyme is stimulated adaptively by the increased amount of substrateheme that is degraded in the mucosal cell. The present findings fail to provide an unequivocal answer to this question because increased hemoglobin iron absorption appears to be linked inextricably to iron deficiency. Although techniques exist permitting manipulation of inorganic iron absorption independently of the organism's iron stores (35-38) no such experimental procedures have been reported for use in the study of hemoglobin iron absorption. However, the following considerations suggest that microsomal heme oxygenase may play an active role in the coordination of heme iron absorption.

In most tissues, heme oxygenase is stimulated by heme, presumably by substrate-mediated enzyme induction (39). One might have anticipated, therefore, that blood in the intestinal tract would enhance the activity of the enzyme in the mucosa. However, no reports exist documenting an increase of fractional hemoglobin iron absorption or of intestinal heme-splitting enzyme activity following prolonged feeding of hemoglobin to experimental animals. Moreover, preliminary observations in rats failed to show a rise of duodenal heme oxygenase activity after peroral administration of hemoglobin or MHA. This appears entirely reasonable because excretory (40) and secretory (41) pathways for excess iron are functionally limited; the adjustment of intestinal iron absorption to need, therefore, appears to be the principal mechanism available to the body for maintenance of internal iron balance. Indeed, if iron absorption were regulated primarily by the heme content of the diet, carnivores would be defenseless against iron accumulation and consequent hemosiderosis. Thus, it would appear to offer a physiological advantage to link control of intestinal heme oxygenase activity to the size or availability of body iron stores rather than to the amount of heme substrate that is present in the intestinal lumen. The mechanism by which the iron requirement of the whole organism modulates mucosal heme oxygenase activity and regulates intestinal heme iron absorption is unknown.

${ }^{8}$ Raffin, S., C. H. Woo, and R. Schmid. Unpublished observations. 
Since heme oxygenase activity has been demonstrated in the intestinal mucosa, it would be expected that in vivo absorbed heme not only releases inorganic iron, but also is a source of bilirubin formation. The metabolic fate of this mucosal bile pigment is unknown; it may be excreted into the intestinal lumen, sloughed with senescent villous tip cells, or absorbed into the portal system. Because in the rat fractional hemoglobin iron absorption is relatively small, the bilirubin formed in the intestinal mucosa probably constitutes an insignificant portion of the total bile pigment produced in this animal. On the other hand, in man where fractional absorption of hemoglobin iron may exceed that of iron salts $(3,4)$, the amount of bilirubin formed from absorbed heme may be proportionally larger. If this bile pigment fraction should gain access to the portal system, it is possible that in iron-deficient patients with upper gastrointestinal hemorrhage, this may lead to a measurable expansion of the body's bilirubin pool. It remains to be determined whether this mechanism may explain the well-documented rise of serum bilirubin concentration in cirrhotic patients with bleeding esophageal varices (42).

\section{ACKNOWLEDGMENTS}

The authors wish to thank Lydia Hammaker, M.S., Antony F. McDonagh, Ph.D., George Brecher, M.D., and Mathews B. Fish, M.D. for their invaluable assistance in various technical aspects of these studies.

This work was supported in part by grants AM 17635 and AM 11275 from the National Institutes of Health, and by the Walter C. Pew Fund for Gastrointestinal Research.

\section{REFERENCES}

1. Walsh, R. J., I. Kaldor, I. Brading, and E. P. George. 1955. The availability of iron in meat. Some experiments with radioactive iron. Australas. Ann. Med. 4: 272-276.

2. Callender, S. T., B. J. Mallett, and M. D. Smith. 1957. Absorption of haemoglobin iron. Br. J. Haematol. 3: 186-192.

3. Turnbull, A., F. Cleton, and C. A. Finch. 1962. Iron absorption. IV. The absorption of hemoglobin iron. J. Clin. Invest. 41: 1897.

4. Björn-Rasmussen, E., L. Hallberg, B. Isaksson, and B. Arvidsson. 1974. Food iron absorption in man. Applications of the two-pool extrinsic tag method to measure heme and nonheme iron absorption from the whole diet. J. Clin. Invest. 53: 247-255.

5. Brown, E. B., Jr., and B. W. Justus. 1958. In vitro absorption of radioiron by everted pouches of rat intestine. Am. J. Physiol. 194: 319-326.

6. Hahn, P. F., W. F. Bale, J. F. Ross, W. M. Balfour, and G. H. Whipple. 1943. Radioactive iron absorption by gastrointestinal tract. Influence of anemia, anoxia and antecedent feeding. Distribution in growing dogs. J. Exp. Med. 78: 169-188.

7. Dubach, R., S. T. Callender, and C. V. Moore. 1948. Studies in iron transportation and metabolism. VI.
Absorption of radioactive iron in patients with fever and with anemias of varied etiology. Blood. 3: 526-540.

8. Conrad, M. E., L. R. Weintraub, D. A. Sears, and W. H. Crosby. 1966. Absorption of hemoglobin iron. Am. J. Physiol. 211: 1123-1130.

9. Wheby, M. S., G. E. Suttle, and K. T. Ford. 1970. Intestinal absorption of hemoglobin iron. Gastroenterology. 58: 647-654.

10. Weintraub, L. R., M. E. Conrad, and W. H. Crosby. 1965. Absorption of hemoglobin iron by the rat. Proc. Soc. Exp. Biol. Med. 120: 840-843.

11. Bannerman, R. M. 1965. Quantitative aspects of hemoglobin-iron absorption. J. Lab. Clin. Med. 65: 944-950.

12. Thomas, F. B., F. S. McCullough, and N. J. Greenberger. 1972. Effect of phenobarbital on the absorption of inorganic hemoglobin iron in the rat. Gastroenterology. $62: 590-599$.

13. Hallberg, L., and L. Sölvell. 1967. Absorption of hemoglobin iron in man. Acta Med. Scand. 181: 335-354

14. Weintraub, L. R., M. B. Weinstein, H.-J. Huser, and S. Rafal. 1968. Absorption of hemoglobin iron: the role of a heme-splitting substance in the intestinal mucosa. J. Clin. Invest. $47: 531-539$.

15. Conrad, M. E., S. Cortell, H. L. Williams, and A. L. Foy. 1966. Polymerization and intraluminal factors in the absorption of hemoglobin iron. J. Lab. Clin. Med. 68: 659-668.

16. Brown, E. B., Y.-F. Hwang, S. Nichol, and J. Ternberg. 1968. Absorption of radioiron-labeled hemoglobin by dogs. J. Lab. Clin. Med. 72: 58-64.

17. Dawson, R. B., S. Rafal, and L. R. Weintraub. 1970. Absorption of hemoglobin iron: The role of xanthine oxidase in the intestinal heme-splitting reaction. Blood. 35: 94-103.

18. Mills, G. C. 1962. Hemoglobin catabolism. III. Conversion of hemoglobin to choleglobin by rat liver preparations. J. Biochem. $51: 41-47$.

19. Bonnett, R., and A. F. McDonagh. 1973. The mesoreactivity of porphyrins and related compounds. Part VI. Oxidative cleavage of the haem system. The four isomeric biliverdins of the IX series. J. Chem. Soc. Perkin Trans. I. 881-888.

20. Gray, C. H., D. C. Nicholson, and G. Tipton. 1972. Degradation of haem compounds to bile pigments. Nat. New Biol. 239: 5-8.

21. Pimstone, N. R., P. Engel, R. Tenhunen, P. T. Seitz, H. S. Marver, and R. Schmid. 1971. Inducible heme oxygenase in the kidney: a model for the homeostatic control of hemoglobin catabolism. J. Clin. Invest. 50: 2042-2050.

22. Tenhunen, R., H. S. Marver, and R. Schmid. 1969. Microsomal heme oxygenase. Characterization of the enzyme. J. Biol. Chem. 244: 6388-6394.

23. Pimstone, N. R., R. Tenhunen, P. T. Seitz, H. S. Marver, and R. Schmid. 1971. The enzymatic degradation of hemoglobin to bile pigments by macrophages. J. Exp. Med. 133: 1264-1281.

24. Schneider, W. C. 1948. Intracelluar distribution of enzymes. III. The oxidation of octanoic acid by rat liver fractions. J. Biol. Chem. 176: 259-266.

25. McDonagh, A. F., and F. Assisi. 1971. Commercial bilirubin: A trinity of isomers. FEBS (Fed. Eur. Biochem. Soc.) Lett. 18: 315-317.

26. Labbe, R. F., and G. Nishida. 1957. A new method of hemin isolation. Biochim. Biophys. Acta. 26: 437.

27. Horrocks, D. L. 1971. Obtaining the possible maximum of 90 per cent efficiency for counting of ${ }^{55} \mathrm{Fe}$ in liquid 
scintillator solutions. Int. J. Appl. Radiat. Isot. 22: 258-260.

28. Conrad, M. E., and S. G. Schade. 1968. Ascorbic acid chelates in iron absorption. A role for hydrochloric acid and bile. Gastroenterology. 55 : 35-45.

29. Stookey, L. L. 1970. Ferrozine-a new spectrophotometric reagent for iron. Anal. Chem. 42: 779-781.

30. Lowry, O. H., N. J. Rosebrough, A. L. Farr, and R. J. Randall. 1951. Protein measurement with the folin phenol reagent. J. Biol. Chem. 193: 265-275.

31. McCall, M. G., G. E. Newman, J. R. P. O'Brien, L. S. Valberg, and L. J. Witts. 1962. Studies in iron metabolism. 1. The experimental production of iron deficiency in the growing rat. Br. J. Nutr. 16: 297-304.

32. Awai, M., and E. B. Brown. 1969. Examination of the role of xanthine oxidase in iron absorption by the rat. J. Lab. Clin. Med. 73: 366-378.

33. Foy, A. L., H. L. Williams, S. Cortell, and M. E. Conrad. 1967. A modified procedure for the determination of nonheme iron in tissue. Anal. Biochem. 18: 559-563.

34. Tenhunen, R., H. S. Marver, and R. Schmid. 1968. The enzymatic conversion of heme to bilirubin by microsomal heme oxygenase. Proc. Natl. Acad. Sci. U. S. A. 61 : 748-755.
35. Hathorn, M. K. S. 1971. The influence of hypoxia on iron absorption in the rat. Gastroenterology. 60: 76-81.

36. Fischer, D. S., and D. C. Price. 1963. A possible humoral regulator of iron absorption. Proc. Soc. Exp. Biol. Med. 112: 228-229.

37. MacDermott, R. P., and N. J. Greenberger. 1969. Evidence for a humoral factor influencing iron absorption. Gastroenterology. 57 : 117-125.

38. Conrad, M. E., L. R. Weintraub, and W. H. Crosby. 1965. Iron metabolism in rats with phenylhydrazineinduced hemolytic disease. Blood. 25: 990-998.

39. Tenhunen, R., H. S. Marver, and R. Schmid. 1970. The enzymatic catabolism of hemoglobin: Stimulation of microsomal heme oxygenase by hemin. J. Lab. Clin. Med. 75 : 410-421.

40. McCance, R. A., and E. M. Widdowson. 1937. Absorption and excretion of iron. Lancet. 2: 680-684.

41. Guy, M. J., and D. Schachter. 1974. Active transport (secretion) of iron by rat jejunum: a new mechanism of iron excretion. Gastroenterology. 66: 842. (Abstr.)

42. Nachlas, M. M., J. E. O'Neil, and A. J. A. Campbell. 1955. The life history of patients with cirrhosis of the liver and bleeding esophageal varices. Ann. Surg. 141: 10-23. 